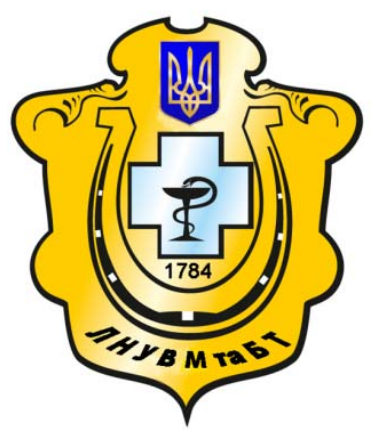

Науковий вісник Львівського національного університету ветеринарної медицини та біотехнологій імені С.3. Гжицького

Scientific Messenger of Lviv National University of Veterinary Medicine and Biotechnologies named after S.Z. Gzhytskyj

doi:10.15421/nvlvet7523

ISSN 2519-268X print

ISSN 2518-1327 online

$\underline{\text { http://nvlvet.com.ua/ }}$

УДК 637.143.2:544.77.051.1:577.118

\title{
Електрофізичний спосіб збагачення сухої молочної сироватки мінеральними елементами
}

\author{
О.В. Кочубей-Литвиненко, О.А. Чернюшок \\ okolit@email.ua \\ Наиіональний університет харчових технологій, \\ вул. Володимирська, 68, Київ, 01601, Україна
}

\begin{abstract}
Стаття присвячена проблемі збагачення мінеральними елементами сироватки молочної внаслідок ії оброблення електрофізичним способом. Об'єкт дослідження: електрофізичний спосіб збагачення молочної сироватки Магнієм та Манганом. Предмет дослідження: знесолена молочна сироватка до та після електроіскрового оброблення, суха демінералізована сироватка (СДМ) та СДМ, збагачена Магнієм та Манганом. Збагачення сироватки $\mathrm{Mg}$ та Мп здійснювали на експериментальному технологічному комплексі, щуо складається з генератора розрядних імпульсів, блоку управління, розрядної камери, вимірювальних і допоміжних приладів. Експериментально доведено, що оброблення молочної сироватки в розрядній камері зі струмопровідним прошарком гранул Магнію і відповідними електродами i/або зі струмопровідним прошарком гранул мангану й відповідними електродами сприяє підвищенню вмісту Магнію у 1,8...3,2 раза й Мангану у 1,9...5,6 раза залежно від тривалості оброблення. Розглянуто доиільність залучення електрофізичного способу оброблення сировини у технології сухої молочної сироватки з метою ї̈ збагачення. Експериментальним иляхом доведено підвищення вмісту Mg $\mathrm{i}$ Mn, nоліпшення розчинності, відсутність ознак неферментативного потемніння протягом зберігання $i$ зниження схильності до злежування в зразках сухої молочної сироватки після оброблення електрофізичним способом. Запропоновано запроваджувати електроіскрове оброблення в технології сухих концентратів із молочної сироватки на етапі підготовки сировини до сушіння та визначено рачіональну тривалість електроіскрового оброблення сироватки, а саме: 30 с - для манганової електродної системи і 60 с - для магнієвої.

Ключові слова: електрофізичний спосіб, електроіскрове диспергування, суха молочна сироватка, збагачення, мікроелементи, магній, манган.
\end{abstract}

\section{Електрофизический способ обогащения сухой молочной сыворотки минеральными елементами}

\author{
А.В. Кочубей-Литвиненко, О.А. Чернюшок \\ okolit@email.ua \\ Национальный университет пищевых технологий, \\ ул. Владимирская, 68, Киев, 01601, Украина
}

\begin{abstract}
Статья посвящена проблеме обогащения минеральными элементами сыворотки молочной вследствие ее обработки электрофизическим способом. Объект исследования: электрофизический способ обогащения молочной сыворотки Магнием и Марганцем. Предмет исследования: обессоленная молочная сыворотка до и после электроискровой обработки, сухая деминерализованная сыворотка (СДМ) и СДМ, обогащенная Магнием и Марганцем. Обогащение сыворотки Мg и Мп осуществляли на экспериментальном технологическом комплексе, состоящем из генератора разрядных импульсов, блока управления, разрядной камеры, измерительных и вспомогательных приборов. Экспериментально доказано, что обработка молочной сыворотки в разрядной камере с токопроводящчим слоем гранул Магния и соответствующиими электродами и/или с токопроводящиим слоем гранул Марганияа и соответствующими электродами, способствует повышению содержания Магния в 1,8 ... 3,2 раза и
\end{abstract}

Citation:

Kochubey-Lytvynenko, O.V., Chernyushok, O.A. (2017). Electrophysical method of dray milk whey enrichment with mineral elements. Scientific Messenger LNUVMBT named after S.Z. Gzhytskyj, 19(75), 115-119. 
Марганцуа в 1,9 ... 5,6 раза в зависимости от продолжстельности обработки. Исследована иелесообразность использования электрофизического способа обработки сырья в технологии сухой молочной сыворотки с ичелью ее обогащения. Экспериментальным путем доказано повышение содержания $\mathrm{Mg}$ и Мп, улучшение растворимости, отсутствие признаков неферментативного потемнения при хранении и снижение склонности к слежсванию в образцах сухой молочной сыворотки после обработки электрофизическим способом. Предложено внедрение электроискровой обработки в технологии сухих концентратов из молочной сыворотки на этапе подготовки сырья к сушке и определена рациональная продолжительность электроискровой обработки сыворотки, а именно: 30 с-для марганцевой электродной системы и 60 с-для магниевой.

Ключевые слова: электрофизический способ, электроискровое диспергирование, сухая молочная сыворотка, обогащение, минеральные элементы, магний, марганеи.

\title{
Electrophysical method of dray milk whey enrichment with mineral elements
}

\author{
O.V. Kochubey-Lytvynenko, O.A. Chernyushok \\ okolit@email.ua
}

National University of Food Technology, Volodymyrska Str., 68, Kyiv, 01601, Ukraine

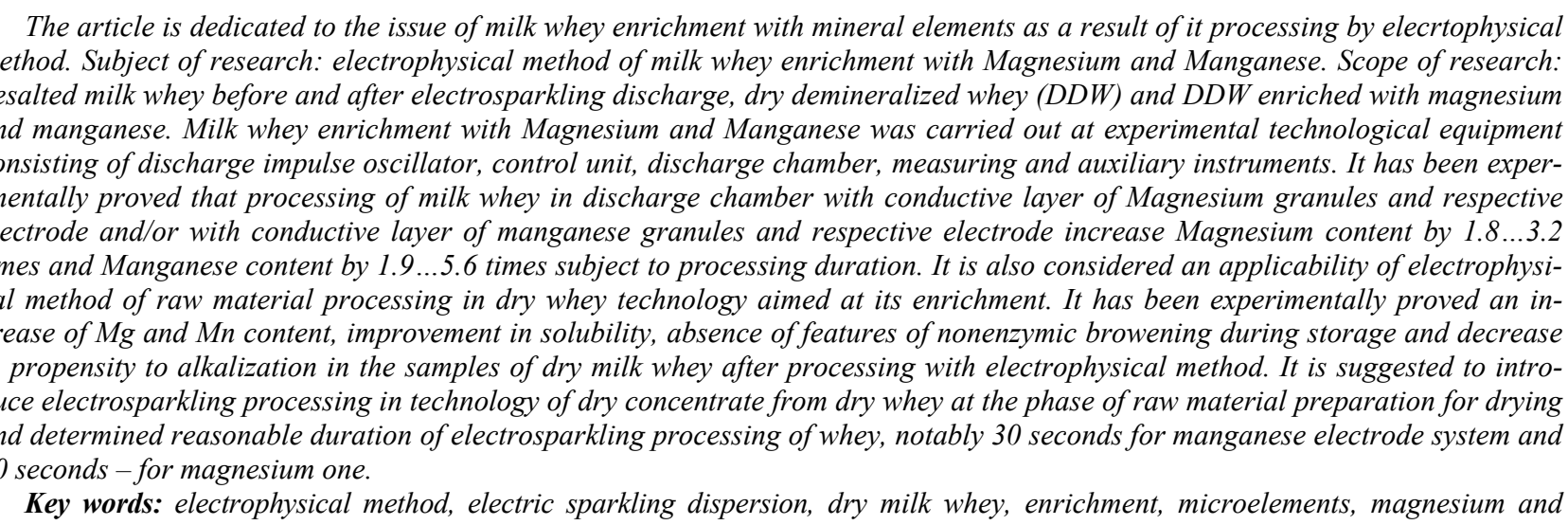
manganese.

\section{Вступ}

Зростання цін на незбиране молоко, нестача сировинних ресурсів, екологічні питання спонукають виробників молочної продукції в усьому світі до раціонального використання вторинної молочної сировини. Зацікавленість підприємств молочної промисловості до переробки молочної сироватки має стійку позитивну динаміку. За даними аналітичної агенції ІНФАГРО, виробництво молочної сироватки в Україні у 2017 році зростає активними темпами. Так, в січні 2017 року цього продукту випущено на 10\% більше порівняно 3 січнем 2016 року. На світовому ринку зростає попит на українську суху демінералізовану сироватку. Обсяги iіi виробництва і споживання в останні роки залишаються незмінно високими. Вона знаходить попит на підприємствах, що виробляють морозиво, молочні, м'ясні, хлібобулочні, кондитерські та інші види харчових продуктів, в тому числі спеціального призначення (De Wit, 2001).

Завдяки запровадженню мембранних методів i електродіалізу суха демінералізована сироватка на відміну від звичайної сухої сироватки характеризується низьким вмістом золи, низькою титрованою кислотністю та приємним солодкуватим присмаком. Залежно від способу виробництва ступінь демінералізації сироватки становить від 25 до 90\%. Відомо, що під час знесолення інтенсивно видаляються одновалентні іони $\left(\mathrm{K}^{+}, \mathrm{Na}^{+}, \mathrm{Cl}^{-}\right)$, що зумовлюють смакові влас- тивості сироватки. 3 підвищенням рівня знесолення видаляються аніони фосфорної і лимонної кислот, що своєю чергою призводить до дисоціації комплексів і видалення двовалентних катіонів $\mathrm{Ca}$ i Mg (De Wit, 2001; Evdokymov et al., 2012; Hondar and Romanchuk, 2015). При електродіалізі дещо знижується вміст Mn (Khramtsov, 2011; Hondar and Romanchuk, 2015). Отже, на рівні з бажаним 3 технологічної точки зору видаленням одновалентних іонів після мембранного оброблення спостерігається зниження вмісту біологічно цінних двовалентних іонів.

Відомо, що $\mathrm{Mg}$ і $\mathrm{Mn}$ необхідні для нормального функціонування організму людини, вони входять до складу багатьох ферментів, які залучаються до обмінних процесів (Spyrychev et al., 2005). Крім того, ці елементи не тільки надають харчовим продуктам функціональних властивостей, а й відіграють істотну технологічну роль. Наприклад, здатні активізувати і стабілізувати дію ферментів дріжджової клітини (Churylyna et al., 2004; Stehlik-Tomas et al., 2004), сприяють зростанню молочнокислої мікрофлори (Kantere, 1990) тощо.

В раціонах харчування переважної більшості населення спостерігається дефіцит цих мікронутрієнтів (Spyrychev et al., 2005). Згідно з критеріями та принципами збагачення, запропонованими ВОО3 (Katserykova, 2004), насамперед належить збагачувати продукти масового споживання тими мікронутрієнта- 
ми, дефіцит яких реально існує і достатньо широко розповсюджений.

Виходячи із постійно зростаючого попиту на суху демінералізовану сироватку, в тому числі в продуктах спеціального призначення, доцільним $\epsilon$ іiі цільове збагачення $\mathrm{Mg}$ та $\mathrm{Mn}$.

Найбільш поширеним способом поповнення дефіциту мінеральних речовин в харчових продуктах $\epsilon$ внесення солей неорганічних кислот. Однак більшість відомих препаратів погано розчиняються у воді, мають неприємний гіркий смак, це може негативно вплинути на органолептичні властивості харчових продуктів, що $є$ неприпустимим згідно 3 вимогами збагачення харчових продуктів (Kukyn, 2013), до того ж мінерали в такій формі мають низьку біологічну доступність. Тому пошук нових способів збагачення харчових продуктів, зокрема молочної сироватки, цінними мінеральними речовинами $\epsilon$ актуальним. Перспективним в даному напрямі $\epsilon$ використання об'ємного електроіскрового диспергування струмопровідних гранул металів у водному середовищі (Lopatko, 2015). Метою роботи було обгрунтування доцільності використання даного електрофізичного методу для збагачення молочної сироватки частинками елементів Mg і Mn.

\section{Матеріал і методи досліджень}

Об'єкт дослідження: електрофізичний спосіб збагачення молочної сироватки Магнієм та Манганом. Предмет дослідження: знесолена молочна сироватка до та після електроіскрового оброблення, суха демінералізована сироватка (СДМ) та СДМ, збагачена Магнієм і Манганом.

Збагачення сироватки $\mathrm{Mg}$ та $\mathrm{Mn}$ здійснювали на розробленому науковцями Національного університету біоресурсів і природокористування України експериментальному технологічному комплексі, що складається 3 генератора розрядних імпульсів, блоку

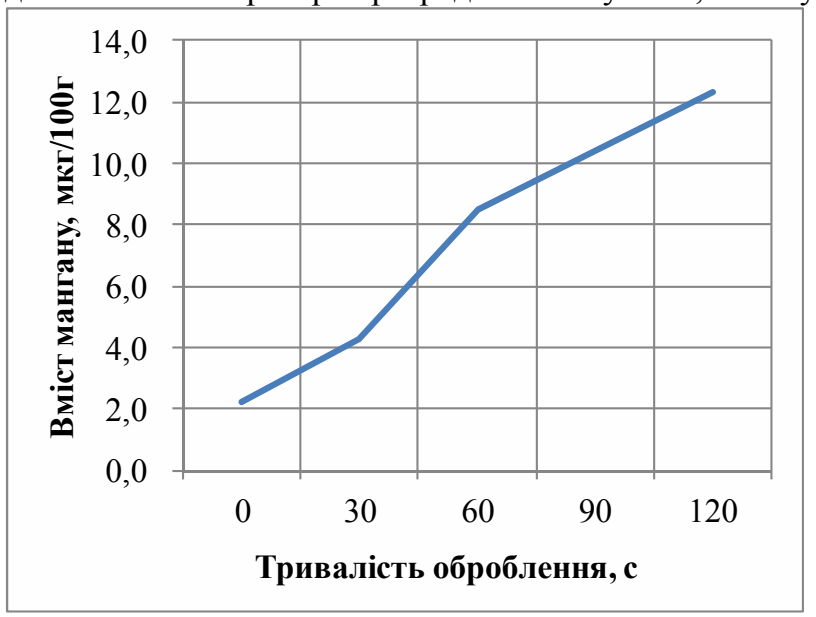

a

\section{Рис.1. Залежність вмісту Мангану (а) та Магнію (б) в знесоленій молочній сироватці від тривалості електроіскрового оброблення}

Проте органолептична оцінка оброблених зразків засвідчила наявність вираженого специфічного смаку і запаху, не властивого натуральній сироватці, та не- управління, розрядної камери, вимірювальних і допоміжних приладів (Lopatko, 2015). Параметри оброблення: напруга зарядки конденсатора $-75 \pm 5$ В; ємність конденсатора - 100 мкФ; проміжок між гранулами металів - до 0,1 мм; частота імпульсів $0,2 \ldots 2,0$ кГц; експозиція - від 30 до 180 с.

Суху демінералізовану сироватку отримували шляхом знесолення підсирної сироватки на нанофільтраційній («GEA», Данія) або електродіалізній («MEGA», Чехія) установках, з подальшим розпилювальним сушінням.

Особливістю отримання сухої молочної сироватки, збагаченої мінеральними елементами, було проведення об'ємного електроіскрового диспергування струмопровідних гранул Магнію і Мангану в середовищі сироватки, знесоленої нанофільтрацією.

В роботі використовували стандартні і спеціальні методи оцінювання органолептичних, фізикохімічних та функціонально-технологічних властивостей молочної сироватки. Вміст металічних елементів визначали методом атомно-абсорбційної спектрометpiï за допомогою спектрометра AAS1N (Carl-Zeiss Jena, Німеччина).

\section{Результати та їх обговорення}

Встановлено, що електроіскрове диспергування гранул металів в молочній сироватці сприяє збагаченню іiі частинками $\mathrm{Mg}$ і $\mathrm{Mn}$, які здатні утворювати органічні сполуки з компонентами сироватки. Останні мають вищу біологічну доступність, оскільки саме в такій хімічній формі функціонують в організмі.

Експериментально доведено, що оброблення молочної сироватки в розрядній камері зі струмопровідним прошарком гранул Магнію і відповідними електродами i/або зі струмопровідним прошарком гранул Мангану й відповідними електродами сприяє підвищенню вмісту Магнію у 1,8...3,2 раза й Мангану у $1,9 \ldots 5,6$ раза залежно від тривалості оброблення.

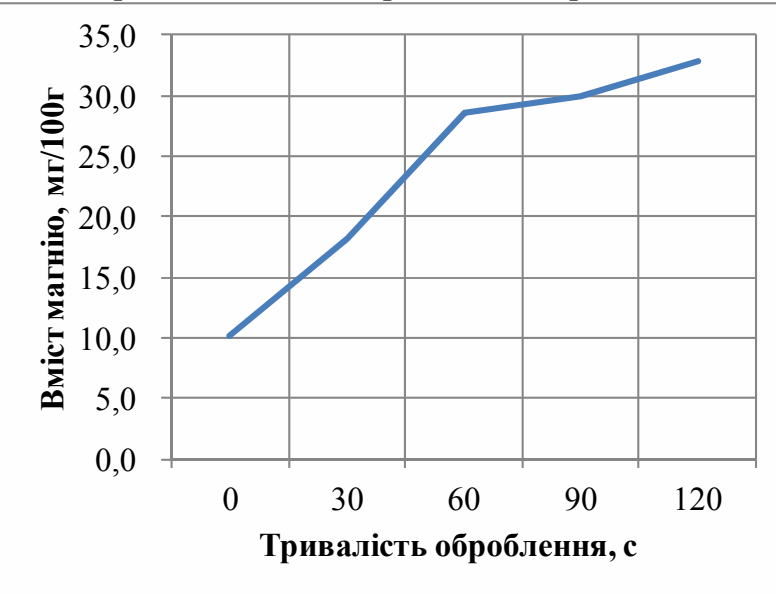

6 бажані зміни кольору під час збільшення експозиції понад 120 с при залученні магнієвих та понад 90 с - 
манганових електродів. За оброблення протягом 30 ... 90 с зберігалися належні органолептичні показники.

Виявлено зниження окисно-відновного потенціалу (зростання антиоксидантних властивостей) в обробленій сироватці з -10 мВ до -70...-290 мВ залежно від тривалості оброблення. Зроблено припущення, що це свідчить як про можливе проходження в системі процесу $\mathrm{Me} \leftrightarrow \mathrm{Me}^{\mathrm{n}+}+\mathrm{ne}$, так i ймовірне комплексоутворення між іонами Магнію і біолігандами, які містяться в сироватці.

Повнофакторним експериментом встановлено раціональну тривалість електроіскрового оброблення сироватки, а саме: 30 с - для манганової електродної системи і $60 \mathrm{c}$ - для магнієвої.

На підставі проведених досліджень обгрунтовано доцільність залучення електрофізичного способу оброблення сировини у технологію сухої молочної сироватки з метою її збагачення. Особливістю запропонованої технології сухої молочної сироватки $\epsilon$ проведення об'ємного електроіскрового диспергування струмопровідних гранул $\mathrm{Mg}$ і $\mathrm{Mn}$ в середовищі знесоленої молочної сироватки. Тривалість електроіскрового оброблення відповідала визначеному раціональному режиму.

Перспективи використання сухої молочної сироватки визначаються ії складом, властивостями та здатністю до зберігання, тому важливим етапом наукових досліджень $є$ визначення функціональнотехнологічних властивостей та стабільності якості продукту при зберіганні. Результати досліджень показників якості та стабільності до зберігання подано в таблиці 1.

Таблииа 1

Показники якості сухої молочної сироватки, отриманої з використанням різних способів оброблення

\begin{tabular}{|c|c|c|c|}
\hline \multirow[b]{2}{*}{ Найменування показника } & \multicolumn{3}{|c|}{ Суха молочна сироватка, вироблена з використанням: } \\
\hline & електродіалізу & $\begin{array}{c}\text { нано- } \\
\text { фільтрації }\end{array}$ & $\begin{array}{c}\text { нанофільтрації та електро- } \\
\text { іскрового оброблення }\end{array}$ \\
\hline Масова частка вологи, \% & 3,6 & 3,0 & 2,2 \\
\hline Вміст $\mathrm{Mg}$, г/кг & 0,90 & 0,93 & 2,9 \\
\hline Вміст Mn, мг/кг & 0,91 & 1,1 & 12,9 \\
\hline Титрована кислотність, ${ }^{\circ} \mathrm{T}$ & 11,0 & 12,0 & 10,0 \\
\hline Індекс розчинності, см $^{3}$ сирого осаду & 0,2 & 0,3 & 0,1 \\
\hline Показник активності води (Aw), ум. од. & 0,245 & 0,196 & 0,130 \\
\hline 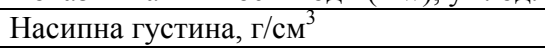 & $0,611 \pm 0,01$ & $0,429 \pm 0,02$ & $0,376 \pm 0,01$ \\
\hline Середній розмір частинок, мкм & 79,7 & 60,3 & 63,6 \\
\hline Ступінь злежування, \% & 17,3 & 16,4 & 2,2 \\
\hline Білизна, ум. од. & 87,8 & 90,6 & 97,4 \\
\hline
\end{tabular}

Дослідження органолептичних, фізико-хімічних та функціонально-технологічних властивостей сухої молочної сироватки, збагаченої $\mathrm{Mg}$ і Mn, засвідчили відсутність негативного впливу електрофізичного оброблення сировини на якісні показники продукту. Навпаки, поряд зі збільшенням вмісту Mg і Mn дослідні зразки збагаченої сухої сироватки мали найкращу розчинність, низьку схильність до утворення грудочок (ступінь злежування не перевищував 3,0\%) та найкращу білизну, при цьому ознаки неферментативного потемніння були відсутніми протягом 12 місяців зберігання.

\section{Висновки}

Електроіскрове диспергування гранул магнію i мангану в середовищі молочної сироватки сприяє іiі збагаченню в біологічно доступній формі частинками магнію в 1,8 ...3,2 раза й мангану у 1,95 ...5,6 раза залежно від тривалості оброблення.

Виявлено зниження окисно-відновного потенціалу (зростання антиоксидантних властивостей) в обробленій сироватці з -10 мВ до -70...-290 мВ залежно від тривалості оброблення.

Доведено збільшення вмісту $\mathrm{Mg}$ і Mn в зразках збагаченої сироватки, поліпшення розчинності, відсутність ознак неферментативного потемніння протягом зберігання і зниження схильності до злежування в сухій молочній сироватці, виробленій із залученням електрофізичного способу оброблення.
Отримані результати засвідчили, що використання електроіскрового оброблення в технології концентратів із молочної сироватки дозволить отримати продукт 3 покращеними функціонально-технологічними показниками, стабільний до зберігання, збагачений цінними мінеральними елементами, що сприятиме розширенню асортименту продуктів спеціального призначення.

Запропоновано запроваджувати електроіскрове оброблення в технології сухих концентратів із молочної сироватки на етапі підготовки сировини до сушіння.

Визначено раціональну тривалість електроіскрового оброблення сироватки, а саме: $30 \mathrm{c}$ - для манганової електродної системи і 60 с - для магнієвої.

Реалізація електроіскрового диспергування струмопровідних гранул Магнію і Мангану в середовищі молочної сироватки не потребує складного технологічного забезпечення, при цьому спосіб характеризується достатньою ефективністю збагачення продукту мікроелементами.

Отже, використання електроіскрового оброблення в технології концентратів із молочної сироватки дозволить отримати продукт з покращеними функціонально-технологічними показниками, стабільний до зберігання, збагачений цінними мінеральними елементами, що сприятиме розширенню асортименту продуктів спеціального призначення.

Перспективи подальших досліджень. Враховуючи сприятливу дію магнію і мангану на зростання моло- 
чнокислої мікрофлори, подальшого дослідження потребує вплив збагаченої сироватки на процес сквашування з метою інтенсифікації виробничих процесів.

\section{Бібліографічні посилання}

De Wit, J.N. (2001). Lecturer's handbook on whey and whey products. Eindhoven: Huntrskil Howard.

Evdokymov, Y.A., Volodyn, D.N., Holovkyna, M.V., Zolotareva, M.S., Topalov, V.K. (2012). Obrabotka molochnoho syria membrannymi metodami. Molochnaia promyshlennost. 2, 34-37 (in Russian).

Hondar, O.P., Romanchuk, I.O. (2015). Zmina mineralnoho skladu sukhoi molochnoi syrovatky za riznykh metodiv obroblennia. Zbirnyk naukovykh prats Vinnytskoho natsionalnoho ahrarnoho universytetu. 1(89), 94-99 (in Ukrainian).

Khramtsov, A.H. (2011). Fenomen molochnoi suvorotky. Spb.: Professyia (in Russian).

Spyrychev, V.B., Shatniuk, L.N., Pozniakovskyi, V.M. (2005). Obohashchenye pyshchevukh produktov vytamynamy y myneralnumy veshchestvamy. Nauka y tekhnolohyia. 2-e yzd. Novosybyrsk: Syb. unyver. yzd-vo (in Russian).

Churylyna, N.V., Matveeva, Y.V., Yudyna, T.A. (2004). $\mathrm{O}$ vlyianyy dobavok myneralnukh solei y fosfolypazu na kachestvo khleba. Khlebopechenye Rossyy. 3, 2426 (in Russian).

Stehlik-Tomas,V., Zetic, V.G., Stanzer, D., Grba. S., Vahcic, N. (2004). Zinc, Copper and Manganese enrichment in yeast Saccharomyces cerevisiae. Food Technology and Biotechnology. 42(2), 115-120.

Kantere, V.M. (1990). Teoretycheskye osnovu tekhnolohyy mykrobyolohycheskykh proyzvodstv: uch. posobye. M.: Ahropromyzdat (in Russian).

Katserykova, N.V. (2004). Tekhnolohyia produktov funktsyonalnoho pytanyia: Uchebnoe posobye. Kemerovskyi tekhnolohycheskyi ynstytut pyshchevoi promushlennosty. Kemerovo (in Russian).

Kukyn, M.Iu. (2013). Razrabotka tekhnolohyi tsytrata ammonyia-zheleza, laktata mahnyia y kompleksnukh pyshchevukh dobavok y ykh prymenenye $\mathrm{v}$ pyshchevukh produktakh: avtoref. ... kand. tekhn. nauk. S.-Peterb. nats. yssled. un-t ynformats. tekhnolohyi, mekhanyky y optyky- SPb., 22 (in Russian).

Lopatko, K.H. (2015). Obgruntuvannia fizykotekhnolohichnykh osnov biolohichnoi funktsionalnosti nanochastynok metaliv: avtoref. dys. ... d-ra tekhn. nauk; NUBiP. K., 46 (in Ukrainian).

Стаття надійшла до редакиії 20.03.2017 